ISSN: 1641-4713; e-ISSN: 2081-1160

DOI: https://doi.org/10.36551/2081-1160.2020.26.161-178

\title{
The making of a visionary culture: connected histories among Marian apparitions in Portuguese-Brazilian world (1917-1936)
}

\author{
La formación de una cultura visionaria: historias conectadas entre \\ apariciones marianas en el mundo luso-brasileño (1917-1936)
}

\author{
Carlos André Silva de Moura \\ University of Pernambuco (UPE), Brazil \\ ORCID iD: https://orcid.org/0000-0002-5584-1398 \\ E-mail: carlos.andre@upe.br \\ Dirceu Salviano Marques Marroquim \\ University of São Paulo (USP), Brazil \\ ORCID iD: https://orcid.org/0000-0001-8451-6239 \\ E-mail: dirceu.marroquim@usp.br
}

Recepción: 5.05.2020

Aprobación: 1.09.2020

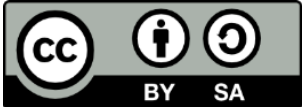

\begin{abstract}
This paper will analyze the shaping of supposed Marian apparitions in Pesqueira, a Brazilian city located in Pernambuco, as part of a series of events related to the devotions to Our Lady representations in modern and contemporary periods. Based on the propositions of Cultural History, regional newspapers, ecclesiastical documents, and personal letters were used in order to understand the relation of these events to political, economic, and social issues of the first half of the $20^{\text {th }}$ century. The analysis will suggest that the events in Pesqueira were connected to other religious representations, such as the apparitions in Lourdes (France) and Fatima (Portugal), reinforcing the image of the $20^{\text {th }}$ century as the "golden century" of apparitions to members and followers of the Catholic Church. Therefore, this work highlights the central performance of ecclesiastics, scholars, and devotees in the shaping of new devotions and cults in a specific space in Latin America.
\end{abstract}

Keywords: Marian apparitions, Catholic scholars, Marian devotions, Portugal - Brazil, Pernambuco.

Resumen: El artículo ha analizado el proceso de construcción de las presuntas apariciones marianas en la ciudad de Pesqueira, ubicada en la Provincia de Pernambuco (Brasil), como parte de una red de eventos en torno a devociones y representaciones de Nuestra Señora en el período contemporáneo. A partir de las propuestas de la Historia Cultural, fueron utilizados periódicos que circularon en la región, documentos eclesiásticos y cartas personales con el objetivo de comprenderse la 
relación de los eventos con cuestiones políticas, sociales y económicas de la primera mitad del siglo XX. Con los análisis, concluimos que los eventos en Pesqueira mantuvieron conexiones con otras construcciones religiosas, como las que pasaron en Lourdes (Francia) y en Fátima (Portugal), reforzando la clasificación del "siglo de oro" de las apariciones para los miembros y fieles de la Iglesia Católica. Para ello, señalamos la actuación de eclesiásticos, intelectuales y devotos como fundamentales para la construcción de nuevas devociones y cultos en un espacio específico de América Latina.

Palabras clave: apariciones marianas, intelectuales católicos, devociones marianas, Portugal - Brasil, Pernambuco.

$[\ldots]$ the history of the "facts" of the apparition was actually an elaboration of the personal, social, and political relations expressed in the conflict of reconstructions. (Apolito, 1992, p. 12) ${ }^{1}$

The theme of Marian apparitions is still little explored by historians. Even though these events occurred in various spaces and temporalities, historiographic discussions in Brazil, for instance, are still concise. Accounts such as those of Sister Amália de Jesus (1930) in Campinas, Maria Milza (1955)², and Pedro Regis (1987) in Bahia, Eduardo and Junior (1988) in Paraná demonstrate the effectiveness of these occurrences in different places, but part of their analysis still focuses on devotional or memorial productions.

Works of anthropologists and sociologists concentrate most of the scientific approaches, seeking to understand the impacts of the events and their social relations in a specific period. However, with the strengthening of the religious studies in leading research centers and the dissemination of information on the apparitions of the early 20th century such as the revelation of the third secret of Fatima or the canonization of the "little shepherds" Francisco Marto (1908-1919) and Jacinta Marto (1910-1920) in 2017, the topic became a theme of investigation in to other areas and a historiographic issue.

To this paper, the propositions of Cultural History were pivotal to the development of the research, considering their focus on religious practices, with a broader discussion beyond investigations centered on ecclesiastical institutions. Therefore, by making an interpretation of the apparitions, this work seeks to understand their political context, their representations and the forms of devotion in the Catholic Church (Burke, 2005, pp. 79, 84), dissociating from a merely descriptive or devotional analysis.

Our investigations about a connected history of apparitions cover the period between the end of the $19^{\text {th }}$ century and the first half of the $20^{\text {th }}$, a moment

\footnotetext{
1 “[...] la storia dei "fatti" dell'apparizione era in realtà una elaborazione delle relazioni personali, sociali e politiche che si esprimeva nella conflittualità delle ricostruzioni".

${ }^{2}$ The Catholic Church members do not consider the events as apparitions; they are called interior locutions, a private revelation heard and/or received by the people involved (Verde, 2016).
} 
marked by events in Lourdes, France (1858); Marpingen (1876); Fatima, Portugal (1917); and Our Lady of Grace in Brazil (1936). Such events contributed to label this period as "the golden century" of Marian worship (Reis, 2001, pp. 272-273). The messages, devotions, and cults involving these episodes became popular, among other issues, due to the work of Catholic scholars on creating an identification with nationality and promoting centrality in Catholicism at a time when secularizing projects were in motion in several Europe and South America nations (Fontes, 2011, p. 91; Catroga, 2006).

The messages attributed to the apparitions, the supposed secrets revealed by the seers, the proposals of devotions, and forms of worship remained connected to political issues such as the war on communism, the defense of conservative propositions, and the discourse of a Catholic-based social order. In Portugal and Brazil, issues such as the consecration of Russia to the Immaculate Heart of Mary, the defense of integralism and the maintenance of specific figures as leaders of the restructuring of the clergy performance in both republics were a constant presence in the supposed dialogues between Our Lady representations and the people involved in these events (de Moura, 2018).

This paper considers the apparitions, the work of scholars and clergy members as the making of a visionary culture, central to the consolidation of the Catholic Church projects, such as the fight against modernism and the process of secularization. We understand this concept as a set of actions, beliefs, news, and messages produced by clergymen and believers which, in a political, social, cultural, and religious context, legitimated and constituted symbolic density to the information on the apparitions, and contributed to the shaping of new events which composed a net of actions that cooperated with the organization of an international devotion.

This work aims to analyze two specific moments of the history of religions in the Portuguese-Brazilian world linked to sociopolitical events in the second half of the $19^{\text {th }}$ century, such as the apparitions in Lourdes and papal documents on the fight against modernism, promoted by Syllabus Errorum (1864) and Rerum Novarum (1891). We approach facts based on concerns and ideas that seek to interpret an international religious context also represented in events as those occurred in Puerto Rico (1955), Venezuela (1976), Nicaragua (1980), Medjugorje (1981), Argentina (1983), among others ${ }^{3}$.

\footnotetext{
${ }^{3}$ We cite apparitions reported during the $20^{\text {th }}$ century using the dates of the first events. We also intend to mention occurrences in Latin America or events that are considered key to the understanding of Mariology in the period of analysis.
} 
Religious events supposedly recorded outside the European continent, especially during the $20^{\text {th }}$ century, were crucial to the decentralization of Marian devotions in the Catholic world. The apparitions in Latin America, for example, contributed to the shaping of important religious practices inside the re-catholicizing clergy projects, besides, aimed at the combat of secularism, the maintenance of the ecclesiastical hierarchy role in political decision making, and the strengthening of public services and activities of the members of the Catholic Church.

Nicola Gasbarro helps us to understand the insertions in the cults related to Marian apparitions and the rise of "new gods". According to the author, each society can deliberately "invent" its own idols, using the codes that involve the community, based on cultural practices within Catholic orthodoxy, defined as orthopractic (Gasbarro, 2013, p. 99).

The concept covers ritual rules and "inclusive and performative actions of social life", with inventions and reinventions in terms of religious practices. Accordingly, this analysis detaches from the classifications attributed to popular Catholicism, since we historicize the arts of making and the forms adopted in the new cults by the followers and leaders of the Roman Church (Gasbarro, 2006, 2014, p. 190). Through this approach, we also avoid generalizations, since we broaden the concept of religion understanding the representations that aspire to the universality, determined by those who produce them (E. M. da Silva, 2012, pp. 103-126).

The supposed apparitions of "Our Lady of the Rosary" to the three children in Cova da Iria, the revelations of the secrets and the establishment of an international cult to the Immaculate Heart of Mary were followed by a political debate on the implementation of a lay culture in Portugal ${ }^{4}$. After the official recognition of the Catholic Church, the leaders of the Roman Curia worked to silence not only the anticlerical actions, but also the speeches that preached the distance between the political and ecclesiastical powers (Barreto, 2002, p. 45).

Similarly, the events that took place from August 1936 onwards in the city of Pesqueira, in the countryside of the state of Pernambuco, the Brazilian Northeast, which had as its main figures, two children from a poor area, Maria da

\footnotetext{
${ }^{4}$ The secrets of Fatima are divided into three parts. The first and second messages were written by Lúcia de Jesus in 1941 and were disclosed immediately afterwards, whereas the third secret was written in 1944 in a letter which should be opened only by the Pope. On June 26, 2000, the Vatican released the last part of the message. The first and the second secrets consist of the vision of hell; devotion to the Immaculate Heart of Mary; the Second World War; and the prediction of the damage that Russia could cause to humanity by abandoning Christianity and joining communism. The third secret refers to the martyrdom of the Church leaders, especially the Pope, in a world in crisis due to the "errors of Russia" spread worldwide. (Bernardino, 2007).
} 
Conceição (1920-1999) and Maria da Luz (1922-2013)5, were essential to the ecclesiastical projects in the country. The messages transmitted to them followed the narratives of salvation of the world through Catholicism and condemnation of communism. Although not officially recognized by the See of Rome, the event was marked by the visionary features found in other places, which keep it connected with the recurring events since Lourdes.

With similar narrative lines, the occurrences in Fatima and Pesqueira emphasize local characteristics, especially those related to political and social issues. While in Fatima the discourse was based on the First World War (1914-1918), the economic crisis and secularism, in Brazil the main topics were drought, cangaço $^{6}$, and common points such as the fight against communism and devotion to Catholicism.

The moment of the apparitions in the city of Pesqueira also followed the necessity to justify the process of reorganization of the ecclesiastical regions in Brazil. The context was characterized by a process of expansion of ecclesiastical power, which took place between 1890 and 1930, "when 56 dioceses, 18 prelatures and three apostolic prefectures were created". For these circumscriptions, "approximately one hundred bishops [were appointed], with the highest percentages in the distribution of circumscriptions and prelates falling to the Northeastern states, São Paulo, and Minas Gerais" (Miceli, 2009, p. 58). In 1912, a newspaper published in Pesqueira reported the numbers of the Catholic Church; in the piece one can note that the country had " 9 archbishoprics, 29 bishoprics, 2 prelatures and 3 apostolic prefectures" ("Miscelanea", 1912, p. 04).

In the geographic space analyzed in this study, the discussions about the changes in the ecclesiastical constituencies met the needs of the representatives of the political and economic powers. As a result, the industrial structure, the strength of civil representatives and the pressure from the main local representatives contributed to the relocation of the Diocese of Floresta to the city of Pesqueira in 1918, which had to be followed by the organization of cults, activities of religious orders and congregations, and the creation of new devotions.

The debates on the political and social context surrounding the apparitions during the $20^{\text {th }}$ century was also held by members of the clergy. At the time of the disclosure of the third secret of Fatima in May 2000, Cardinal Joseph Ratzinger,

\footnotetext{
${ }^{5}$ On June 12, 1940, Maria da Luz Teixeira de Carvalho joined the Congregation of Christian Instruction and adopted the ecclesiastical name of Sister Adélia.

${ }^{6} \mathrm{An}$ armed group, active in several areas of Northeast Brazil from the $18^{\text {th }}$ to $20^{\text {th }}$ centuries, organized as a form of defense and resistance of part of the population to the absence of the State. Part of the historiography classifies the cangaceiros, members of the groups, as "social outlaws" due to the various acts of violence in their actions.
} 
then the Prefect of the Congregation for the Doctrine of the Faith, published the text "Theological Commentary" with matters concerning the interpretations of Marian apparitions. In his writings he emphasized the events around Fatima, along with some reflections on the messages disclosed by Sister Lúcia de Jesus.

Concerning the third secret, the German Cardinal questioned whether the dialogues translated by the visionaries really reflected Mary's words, "[...] Or perhaps are they just projections of the inner world of children, grown up in an atmosphere of deep piety, but at the same time frightened by the storms that threatened their time?" (Ratzinger, 2000). It is important to note that one of the links among modern apparitions is the characterization of spaces and people, with children as protagonists, in places with limited resources, social problems, and interference in the daily life of each locality.

Even if Ratzinger's work aims to understand the event in a devotional way, the reflection leads us to think about the process of creating the legitimacy of the apparitions in both places. In Pesqueira, one of the features was the denial by members of the families of the central figures, by part of the population, members of public power, and some representatives of the Catholic Church, along with the silencing of the news.

It is important to stress that the events surrounding the apparitions in the first half of the $20^{\text {th }}$ century had to observe the legislation established by the 1917 Code of Canon Law. The document provided a list of prohibitions on disclosures, such as books containing information about devotions, cults, or events such as apparitions. According to the document:

Book prohibition [...] They are forbidden in themselves: the Eastern Church's editions of Scripture, also by a non-Catholic; books defending heresies, schisms or which are against the fundamentals of faith and religion or morality; by non-Catholics, regarding previously professed religious men; books disseminating apparitions, revelations, visions, prophecies, miracles, unapproved new devotions; those attacking dogma, spreading condemned errors; those against discipline, hierarchy, the clerical or religious state; those with superstitions, spells, divinations, magic, spiritism, etc... or those in favor of dueling, suicide, divorce, Freemasonry and similar sects; those which narrate or teach lascivious things; liturgical editions not in conformity with the authentic one, from apocryphal indulgences, proscribed or revoked; those with images different from the decrees and traditions of the Church. (La Puma, 1917, p. 243) ${ }^{7}$

\footnotetext{
7 "Proibizione dei libri [...] Sono per se stesse proibite: le edizioni scritturali, anche della Chiesa Orientale, fatte in Oriente anche da un acattolico; i libri che difendono eresie, scismi o sono contro i fondamenti della fede e della religione o il buon costume; di acattolici che trattano ex professo di religione; i libri che divulgano apparizioni, riyelazioni, visioni, profezie, miracoli, devozioni nuove senza approvazione; quelli che attaccano il domma, diffondono errori condannati; quelli contro la disciplina, la gerarchia, lo stato clericale o religioso; quelli con superstizioni, sortilegi, divinazioni, magie, spiritismo, ecc., o che sono a favore del duello, suicidio, divorzio, massoneria e simili sètte; che narrano o insegnano cose lascive; le edizioni liturgiche non conformi alle autentiche, di indulgenze apocrife, proscritte o revocate; di immagini difformi dai decreti e usi della Chiesa".
} 
The code sought not only to regulate the forms of recognition of religious devotions, but also to demonstrate the caution of the hierarchy concerning the events surrounding Catholic cults. Thus, part of the accounts of visions, prophecies, or revelation phenomena ended up in cases dismissed by members of the Roman Curia.

It is in this context that we identify the importance of scholars and ecclesiastics in the making of the event as a religious practice. Both in the events around Fatima and in Pesqueira, the discussions needed the intervention of the clergy to recognize its validity, with actions that made possible the creation of new spaces of devotion.

It is important to stress that in Pesqueira there are no clergy documents which formally recognize the supposed apparitions started in 1936. However, we have identified the unofficial validation of ecclesiastics, with permanent assistance to the believers, the maintenance of religious practices, the organization of a devotional calendar and the structuring of the physical space for the pilgrimages.

In Portugal, $O$ Seculo was the first nationwide newspaper to report the Marian apparitions in the country. The story published on July 23, 1917 only presented the news, without an analysis or criticism of what had happened. Liberdade was the pioneer publishing among Catholics with a descriptive piece on August 17, 1917 (Reis, 2001, p. 253).

In May 1931, Brotéria magazine published an analysis of the similarities between the apparitions of Our Lady of Fatima and those that occurred in Lourdes. In the discussion, the author presented the account of Maria dos Santos, who accompanied the revelations of the "Lady of the Rosary", except for the one which occurred on May 13, 1917. Santos reported:

At the appointed hour the three children appeared, and here, under this holm oak tree, they prayed the rosary. At the end, Lúcia stood up, straightened her shawl and the white scarf covering her head, composed herself as if to enter a church, and turned to the East, awaiting the vision. To the people there who asked if there was any delay, she answered there was not. The two cousins insisted that there was still time to pray the rosary, when Lúcia manifested the impulse of surprise, saying: "The lightning has already been seen, the Lady is coming" and ran to the holm oak, following her cousins. I heard what Lúcia said to the vision, but I did not see anything, nor did I hear any answers. I noticed something remarkable, however. It was in June; the holm oak had all her tops covered with new, long shoots. When Lúcia, at the end of the apparition, said that the Lady had gone to the East, all the shoots of the holm oak were bedridden and facing East, as if the edge of the Lady's dress had brushed against them when she departed. (Tavares, 1931, pp. 279-280) ${ }^{8}$

8 “Á hora aprazada appareceram as três crianças, e aqui, debaixo desta azinheira, rezaram o terço. No fim levantou-se a Lúcia, ageitou o chalé e o lenço branco que lhe cobria a cabeça, compôs-se 
Maria dos Santos' account indicated one of the main distinctions between the vision, as something private, and the apparition, as the moment when there is "proof" of the phenomenon by others in attendance. Even without seeing the image of Our Lady of Fatima, the inhabitants of the region highlighted the movement of the holm oak as a "verification" of her presence.

It is worth noticing that Liberdade had a publishing profile that did not indicate any friction with the religious issues of the country. Unlike other newspapers, such as $O$ Seculo, the quoted documents contributed to the making of narratives about the events in Portugal, with statements and texts by the believers and ecclesiastics.

What happened between May and October 1917 in Portugal was important to reinforce the role of the Catholic Church and the political re-establishment of the institution in the country. With the establishment of the cult of Our Lady of Fatima from 1930 onwards, after the release of the Pastoral Letter on the cult of Our Lady of Fatima, published on 13 October 1930 by Bishop José Alves Correia da Silva (1920-1957), conversions to Catholicism, the defense of nationalism, and criticism of secularism and republican anticlericalism were resumed (Simpson, 2014, p. 35).

The apparitions reported by Maria da Conceição and Maria da Luz, which took place at Sítio Guarda, Vila de Cimbres, in the city of Pesqueira, began on August 6, 1936, and were recorded until the death of the two figures. The area was a poor place, which suffered from drought and the onslaughts of armed groups, such as the cangaceiros, who caused apprehension among the locals.

The fear of the onslaught by the armed groups was directly linked to the actions conducted between the months of May and August 1936, with news that one of the most important gangs had entered the Sertão of Pernambuco through the state of Paraíba (“'Lampeão' está em território pernambucano”, 1936, p. 1; “Lampeão em território pernambucano?", 22 May 1936, p. 3) $)^{9}$. The circulation

\footnotetext{
tôda como para entrar numa igreja, e virou-se para o nascente, aguardando a visão. Ás pessoas presentes que lhe perguntavam se havia demora, respondia que não. Os dois primos insistiam em que ainda havia tempo para rezarem o terço, quando Lucia manifestou o impulso de surpresa, dizendo $<<$ já se viu o relâmpago, já lá vem a Senhora $>>$ e correu para a carrasqueira, seguindo-a os primos. Ouvi o que Lúcia disse à visão, porém não vi nada, nem ouvi respostas. Reparei contudo numa coisa notável. Era em junho; a carrasqueira tinha tôda a copa coberta de rebentos novos, compridos. Quando a Lúcia, terminada a apparição, significou que a Senhora se havia ido para a banda do nascente, todos os rebentos da carrasqueira estavam acamados e voltados para o oriente, como se a orla do vestido da Senhora, ao partir, tivesse roçado sobre êlles".

${ }^{9}$ The Jornal Pequeno reported that the armed group had passed through Povoado de Mimoso, located in the city of Pesqueira.
} 
of information on the crimes and various forms of violence in the area were topics of conversation and a reality of daily life among children, who were not far from the main issues of workers, the family, and spaces of sociability.

The Jornal Pequeno, a newspaper distributed in several cities in Pernambuco, was one of the first media outlets to report the events of the supposed apparitions in the city of Pesqueira, in a story published on September 2, 1936. According to the newspaper, the village of Cimbres was taken by:

An uncountable crowd [...] [who] sought out the place where two children would have seen the image of Our Lady. The news of the miraculous event soon reached the ears of all the sertanejos, who, full of faith and confidence in the power of Mary Most Holy, left their homes in search of the place where such a phenomenon took place ("Visão confortadora!", 1936, pp. 1-2). ${ }^{10}$

The following days were marked by mistrust of family members, the silence of ecclesiastical authorities, and an attempt by the government to interrupt religious practices. Due to the mobilization on the area since the first visions, the making of a visionary culture in Pernambuco became a police matter, with the arrest of Maria da Luz's parents, the displacement of armed detachments for the surveillance of the area, and threats to popular demonstrations.

However, as we can see in the fragment of the piece, information about the apparitions of Our Lady of Grace was followed by a process of legitimization by the believers who, in an area with different social problems, sought connections with the divine. It is important to emphasize that since the first news, the association of the event with the representations of the cangaços as a violent group was a constant among the seers. Also, the Jornal Pequeno presented the narratives that supposedly marked August 6, 1936, with perceptible insertions of daily questions in the dialogues with the religious representation. The newspaper stressed that:

[...] the girls [...] daughters of poor parents, living in the village of Cimbres, were lost in the forest. Lourdes ${ }^{11}$, less courageous than her sister, soon began to worry about the situation in which she found herself in the realm, and turning to Maria, she said:

- What would become of us if Lampeão appeared?

- And the little sister answered

- Our Lady would help us...

And as if by magic, a great stone close to them became the most beautiful vision of the Blessed Mother. The two sisters, overwhelmed by the marvelous spectacle of a sweet joy, knelt down giving thanks to the Mother of Heaven.

\footnotetext{
10 "Uma multidão incalculável [...] [que] procurava o local onde duas crenças teriam visto a imagem de Nossa Senhora. A notícia do milagroso acontecimento logo chegou aos ouvidos de todos os sertanejos, que cheios de fé e confiança no poder de Maria Santissima, abandonaram as suas casas à procura do local onde tamanho phenomeno se havia operado".

${ }^{11}$ The story names the children as Lourdes and Maria, and they are referred to as sisters. However, the names of the children are Maria da Luz Teixeira de Carvalho and her friend Maria da Conceição Silva.
} 
Our Lady then spoke to the girls:

- My daughters! Remain firm in the purity of our feelings and the purity of your faith.

God's blessing will confirm the virtue of your virginity. It is for you that the world still deserves from the Father the blessing of his mercy. The virgin will thus make use of the presence of those maidens to give an example of what faith and purity of intentions are worth. Surprised by such sublime words, uttered with an inexplicable tenderness that only the saints are given this merit, the young girls were shaken in their natural astonishment without being able to utter a word when Our Lady went on:

- My daughters! Remain in the purity of our faith, and at 8 o'clock on Monday, I will again be here to comfort you. And so, suddenly, that heavenly vision that brought to the hearts of children [...] the comfort of the word of heaven disappeared ("Visão confortadora!", 1936, pp. 1-2). ${ }^{12}$

It is important to highlight that the Jornal Pequeno had already covered religious events. In several of its issues it is possible to identify cases that could arouse great interest on the part of readers, which object was a connection between the earthly world and something that was outside it.

The piece "Olinda Misteriosa" ["Mysterious Olinda"] is an example. It reported the incident of the "ghost sailboat of the Tapado River", seen by "black Inácia", and it stated that "the people's beliefs have forged, through the centuries, an extensive series of facts covered with fantastic, absurd characters" ("Olinda Misteriosa", 1934, p. 1). This was also the case with the "supposed appearance of a saint" in Alto do Cabeço Zibreira, near Lisbon, where Saint Anne allegedly appeared to a shepherd on July 1, 1936. ("Suposta aparição de uma santa", 1936, p. 3)

Another fact that illustrates our purpose is that of "Santa de Tegipió", "sister Izabel", who lived in a poor house in the city of Recife, capital of

12 " [...] que as meninas [...] filhas de paes pobres, residentes no povoado de Cimbres, perderam-se na floresta. Lourdes, menos corajosa que a irmã, logo começou a se preocupar com a situação em que se encontrava no ermo, e voltando-se para Maria disse:

- Que seria de nós se aparecesse Lampeão?

- E a irmãzinha respondeu

- Nossa Senhora nos valeria...

E como por encanto, uma grande pedra próxima do logar, transformou-se na belíssima visão da Virgem Santissima. As duas irmãs, confundidas ante aquelle maravilhoso espectaculo em transporte de uma doce alegria ajoelharam-se dando graças a Mãe do Céo.

Nossa Senhora, então, falou ás meninas:

- Minhas filhas! Continuae firmes na pureza de nossos sentimentos e na pureza de vossa fé.

A bençam de Deus confirmará a virtude de vossa virgindade. Por vós é que o mundo ainda merecer do Pae a bemaventurança de sua misericórdia. A virgem se servira assim da presença daquelas donzelas para dar um exemplo do que vale a fé e pureza de intenções. Surprehendidas com tão sublimes palavras, pronunciadas com uma ternura inexplicável que só aos santos é dada esse merecimento, as mocinhas se abalaram no seu natural espanto sem saber pronunciar uma palavra, quando nossa Senhora prosseguia:

- Minhas filhas! Continue na pureza de nossa fé e segunda-feira as 8 horas, de novo, estarei aqui para vos confortar. E assim, desapareceu, de repente, aquella visão celeste que trouxe aos corações infantis $[\ldots]$ o conforto da palavra do ceu". 
Pernambuco, and whose description identifies her as a miracle worker. Despite the actions of confronting the clergy themselves, "what is real, undeniable, is that in spite of these opposing opinions, the pilgrimage to Tegipió is still intense, where the saint is, still doing her charity, she says, and it will last four years" ("A 'Santa' de Tegipió", 1931, p. 1). This event, despite having become a police matter, like the apparitions in Cimbres, revealed an editorial interest in subjects that could spark the readers' imagination by making them spend two hundred (\$200) réis for a copy of the newspaper.

Returning to our discussions in the case of Cimbres, it is possible to notice that the narrative of the supposed dialogues between the children and Our Lady followed the themes found in other events of the modern period, based on the apparitions at Lourdes. Adapting them to the social context of the area under analysis, Mary's supposed messages reaffirmed the need for devotion to Catholicism, the maintenance of ecclesiastical practices, and the importance of religion in a moment of formation of eschatological discourses.

News related to the actions of cangaceiros maintained close connections with the economic situation of the area. During the first half of the $20^{\text {th }}$ century, the city of Pesqueira was one of the main economic routes, with the development of the candy industry and its by-products, attracting international investments and maintaining trade with small and large producers. Such issues were significant for the actions of these figures, which were confronted in different ways, including religious issues.

The narratives elaborated by the seers and part of the clergy were also in line with the re-catholicizing project, the expansion of Catholic teachings and the creation of new devotions, based on an international project to reaffirm the political power of the Church and its members (de Moura, 2018). The Marian apparitions in Pernambuco were essential, for instance, in the fight against the Protestant missions in the "hinterlands of Brazil", such as the work developed by members of the Presbyterian and Baptist Churches in the state (Cf. E. M. da Silva, 2010; P. J. da Silva, 2016).

The events in Pesqueira were also characterized by the elaboration of a thaumaturgy process of the space of the apparitions. As we can see in the cities of Lourdes and Fatima, the devotional moments were followed by demonstrations of Mary's presence to people other than the children. The story published in the Jornal Pequeno closed with a special highlight:

In the midst of that crowd there was an old sertanejo, chief of numerous offspring. Although he was a disbeliever of the miraculous phenomenon, he was bringing a sick daughter so that the Virgin could cure her. His wife, pious and good, without losing the faith of an old sertanejo mother, then remembered to lay her daughter's hand on the miraculous slab. 
Suddenly, to the general amazement of that crowd, the young lady gave a cry of satisfaction, knelt, kissing the stone, still moved by the miracle of healing. And the old unbeliever, overwhelmed with such power of divine goodness, knelt, weeping, giving thanks to the Virgin for the great miracle of his daughter's health ("Visão confortadora!", 1936, pp. 1-2). ${ }^{13}$

The healing of a child can be considered the demonstration of the presence of Mary's representation, and especially the reaffirmation of a net of events around the apparitions based on the configuration of a visionary culture and uses for the creation of new devotions for the Catholic Church. The acceptance of the concept of revelation or apparition by members of the Roman Church is relevant because one of its requirements is the need to become a public moment. This differs from the term vision, which is understood as a private moment, with aspects that are restricted to inner feelings (Barreto, 2002, p. 65; Christian Jr., 1996; Ratzinger, 2000).

Information about the healing of a child in the apparition is not limited to a possible solution of a health problem. The descriptions of his parents, characterized as an incredulous man and a woman of faith, are important narratives to the shaping of devotions and conversions in the space designated for the events. In addition to the messages attributed to Mary and the dialogues with the children, the moment was also marked by healings and conversions to Catholicism in an instant of formation of a new Christianity, and rearrangement of the ecclesiastical circumscriptions and justification of a diocese in the area.

Maria da Luz's family registered and interpreted the place of the supposed apparitions based on the relatives' and devotees' narratives and the accounts published by the press. In the image one can see the place of the supposed apparitions, and a stone with a clear mark used as one of the proofs for the apparition of Our Lady of Grace. Through the accounts, the site is now represented as a place of devotion to the sacred.

Hence, the village of Cimbres contributed to the decentralization of Catholic cults, not only concentrating on urban centers, but also expanding to places far from capital cities, with essential features for the reaffirmation of a net of Marian devotion connected with other areas with similar characteristics. The Pernambuco press has emphasized that "The news that runs through the backlands

\footnotetext{
13 "No meio daquela multidão surgia um sertanejo idoso, chefe de numerosa prole. Descrente embora do milagroso fenômeno conduzia uma filha enferma para que a Virgem a curasse. Sua esposa, piedosa e boa, sem perder a fé de velha mãe sertaneja, lembrou-se então de tocar com a mão da filha á lage milagrosa. De momento, para espanto geral daquela multidão, a mocinha dando um grito de satisfação, ajoelhou-se, beijando a pedra, ainda com a emoção que lhe produzia o milagre da cura. E o velho incrédulo, abismado com tamanho poder de bondade divina, ajoelhou-se chorando, dando graças á Virgem pelo grande milagre de saude da sua filha".
} 
$[\ldots]$ has led [...] to Cimbres [...] far more than three thousand people. [...] as reported by our correspondent [...] each day increases the number of pilgrims, anxious to see the Saint or hear from the girls, who have this privilege, words of comfort". ("No logar onde apparece a Santa está jorrando agua milagrosa", 1936, p. 1).

IMAGE 1: MARIA DA LUZ, MARIA DA CONCEIÇÃO AND HER FAMILY, WORKERS AND FRIENDS IN THE PLACE OF THE SUPPOSED FIRST APPARITION

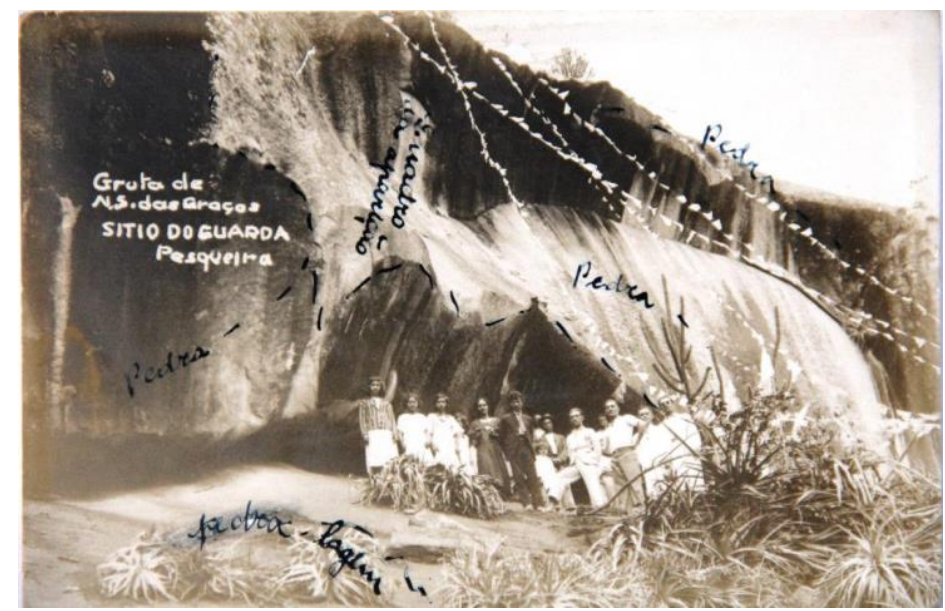

Source: Arquivo da Diocese de Pesqueira.

Rafael Maria Francisco da Silva presented a discussion on the formation of narratives around the characters and the apparitions, emphasizing the miraculous character and the making of a discourse based on nationality. According to the author, "for twenty-six days, with Maria da Luz, she [Maria da Conceição] was the leading figure in the confidences and supplications of Our Lady in favor of Brazil and the conversion of the people. She is the one who identifies the rays that come from the hands of the Virgin, symbol of the graces we have been granted" (R. M. F. da Silva, 2016, pp. 23-24).

The author's narrative demonstrates the devotional character of some of the analyses about the supposed apparitions in Pesqueira. The discourse is central to our understanding of the creation of a visionary culture in the area, especially the connections of the event with the political context, the movements supporting ecclesiastical projects against communism, the process of the state secularization and nationalist discourses.

However, the proposals to establish Cimbres as a space of devotion and the insertion of the event into a visionary net in the $20^{\text {th }}$ century began in the first weeks after the two children's reports. Even with the apprehension of members of the 
Catholic Church in the area, Father José Kehrle (1891-1978) and Friar Stephen Rotger (1877-1955) were in charge of attesting to the "accuracy" of the reports.

Both ecclesiastics were appointed by the local bishop, Adalberto Accioli Sobral (1934 - 1947), to conduct inquiries with the children, their families, and the population. As a methodology for the elaboration of a report to the clergy leaders, the clergymen questioned the children and visited the location where the apparitions supposedly took place (R. M. F. da Silva, 2016, p. 33).

One of the main defenses of the accuracy of the statements is based on the form of investigation carried out by Father José Kehrle. According to the reports, the clergyman made all the questions in German, his mother tongue, and the children answered in Portuguese. In order to justify the interpretation of the dialogues between the priest and the children, the questions would have been made to Our Lady of Grace and the children would have given the answers, that is, acted as representative for Mary's representation. Such a conclusion contributes to reaffirm the establishment of the apparition as a public event, with the participation of people other than the seers and the Marian figure.

Among the questions raised in one of the sessions, one can see that the theme was directed towards the possible messages left by Our Lady of Grace, especially on political issues of that moment. During the questioning, the priest asked the children:

1 - The apparitions in Genipapinho are from God?

Yes, you can believe it.

[...]

3 - Why was there this new apparition?

Daughter it is because I am only looking for the conversion of all sinners.

4 - Is it true that you see 3 days of darkness?

Jesus will command if you do not do strong penance.

$[\ldots]$

6 - Which will be the punishment?

The punishments many places are already seeing and that is what they are if you continue.

7 - Will communism still come to Brazil?

If you don't pray.

8 - Is it convenient to help integralism?

If you want to.

9 - Or will integralism be in the future a ruin for the Church?

Daughter do not fear because nothing harmful shall come to your side.

$[\ldots]$

28. How long will the persecution continue in Germany?

If you do not pray and do not do penance.

29. What you told me about communism in Brazil, will it come true?

Daughters, what I want you to do is pray and Jesus will forgive the sins you have committed;

$[\ldots]$ 
31. Any more blood will be spilled? In Brazil?

Jesus says if you don't do penance, it will spill, a lot.

32 . Will the penalties still come in the current regimen?

Jesus promises to keep it that way. [...]

(Diocese of Pesqueira, 1937) ${ }^{14}$

The analysis of the inquiry shows that the questions were not only intended for theological issues, but addressed specific points about the politics of the 1930s, such as the communist "threats", the rapprochement of members of the Catholic Church with Ação Integralista Brasileira ${ }^{15}$, and the conflicts in Germany. The direct condemnation of communism and the flexibility with integralist ideas demonstrate that the events in Pesqueira, as well as those in Fatima, were also used to justify a political discourse.In the 1930s, the city of Pesqueira was one of the main centers for the spread of Ação Integralista Brasileira in the state of Pernambuco. Many political representatives supported the group and contributed to its expansion in the area, justifying the social discourse based on the motto "God, Homeland and Family" (Amorim, 2002).

14 "1 - As apparições em Genipapinho são de deus?

São, podem crerem.

$[\ldots]$

3 - Por que motivo houve esta nova apparição?

Filha é porque eu so ando procurando a converção de todos os pecadores.

4 -É verdade que vêem 3 dias de escuro?

Jesus mandará se não fazeres penitencias forte.

$[\ldots]$

6-Quaes serão os castigos?

Os castigos muitos lugares já estão vendo e são estes mesmo se assim continuarem.

7 - O communismo ainda virá ao Brazil?

Si não rezarem

8 - É conveniente de auxiliarmos o integralismo?

Si quizereis.

9 - Ou será futuramente o integralismo em ruina da egreja?

Filha não temas que nada virá mal para teu lado.

[...]

28. Ainda continuará muito tempo a perseguição na Allemanha?

Si não rezarem e não fazerem penitencias.

29. Ainda se realizará o que a senhora me disse sobre o comunismo no Brazil?

Filhas o que pesso é que rezem que Jesus perdoará as penas cometidas;

$[\ldots]$

31. Ainda há de correr sangue? No Brasil?

Jesus diz que se não fizerem penitencias, correrá, muito.

32. Os castigos ainda virão no actual regimen?

Jesus pormete si assim continuarem. [...]"

${ }^{15}$ A mass cultural and political movement established in October 1932 by the intellectual Plínio Salgado, whose motto was "God, Homeland and Family". Among its supporters were members of the Catholic Church, one of the main doctrinal pillars of the group. (Cf. Silva, 2017; Trindade, 1979). 
In the course of the integralist activity in Brazil, the main leaders of the sigma $^{16}$ ranks, such as Plínio Salgado (1895-1975) and Gustavo Barroso (1888-1959), employed church discourses to justify the proposals presented in the 1932 Manifesto of Ação Integralista Brasileira (Salgado, 1955). To develop the A.I.B. projects, the group created partnerships with members of the clergy, like Father Helder Câmara (1909-1999) and Bishop Sebastião Leme (1882-1942), in order to develop strategies to combat common enemies, such as communism. It is in this sense that we understand how "[...] the religious informs the political to a great extent, and also the political structures the religious" (Coutrot, 2003, p. 335).

It is worth mentioning that in Portugal, in messages attributed to the visionary Alexandrina Balasar ${ }^{17}$, the importance of Oliveira Salazar for the re-catholicizing moment in the country was highlighted. In her correspondence addressed to Catholic leaders, the visionary stated that Jesus Christ stressed that "[...] it is [Salazar], [who] puts an end to so much sin. He will ask him to do more for the cause of God and for Portugal" (Arquivo Histórico do Patriarcado de Lisboa. 1940).

It is based on these questions that we identify the formation and direction of the events surrounding the apparitions in the first half of the $20^{\text {th }}$ century, with clerical representations aimed at conservative political proposals, criticizing anticlericalism and the detachment of political and religious powers. The proposals were part of a set of practices, which we classify as a network, carried out by Catholic ecclesiastics and scholars for the making of a visionary culture of support for the projects of the Roman Curia and the formation of a neo-Christianity committed to these goals.

The defense of specific governors, such as Oliveira Salazar in Portugal, or of political thoughts, such as integralism in Brazil, not only demonstrated the clergy's support for a line of thought but was also used as a form of criticism of left-wing thinking. The apparitions at Fatima were aligned with the fight against anticlericalism and the rise of Salazarism, actions that were emphasized with the arrival of the ruler at the Ministry of Finance in 1928. In Pesqueira, the defenses to integralism were aligned with criticisms of left-wing movements in Brazil from 1935 onwards.

The analyses of the events that took place in the Luso-Brazilian world represent one part of various episodes in the "golden century" of Marian

\footnotetext{
${ }^{16}$ Symbol used by the members of Ação Integralista Brasileira.

${ }^{17}$ Alexandrina Maria da Costa (1904-1955) was born in the parish of Balazar, district of Porto, northern region of Portugal. Alexandrina Balasar's life was full of accounts of her physical and moral suffering, visions, demonic possessions, mortifications, ecstasies and supernatural phenomena. In 2004, Pope John Paul II beatified the seer, recognizing her for her devotion to God. (Cf. Lopes, 2012, pp. 90-92; Marques, 2012).
} 
apparitions. Other events followed similar regulations, even though they protected the historical, social and political characteristics of each location. Following the supposed apparitions in Pesqueira, the Catholic Church in Brazil watched the process of the creation of new devotions in Latin America, using the cult of Mary's representations as a vehicle for the political strengthening of the clergy at a time of secularization. Although in a different way, the events that took place in the first half of the 20th century continue to be a subject of debate among Catholic Church leaders. Some of their figures, such as Sister Lúcia de Jesus in Portugal and Sister Adélia (Maria da Luz) in Pesqueira, pass through a process of thaumaturgy as part of a long journey towards canonization, crucial points to validate the apparitions and the work of recognition of the Roman Church.

\section{REFERENCES}

A "Santa" de Tegipió. (1931, May 19). Jornal Pequeno, 1.

Amorim, F. L. (2002). Uma Cidade Germanófila, em 30. O integralismo em Pesqueira. Universidade Federal de Pernambuco.

Apolito, P. (1992). Il Cielo in Terra. costruzioni simboliche di un'apparizione mariana. Il Mulino.

Arquivo Histórico do Patriarcado de Lisboa. (1940). Carta de Alexandrina de Balasar ao Presidente do Conselho de Ministros António Oliveira Salazar. PT/AHPL/PAT 14-SP/I-07/01/001/01.

Barreto, J. (2002). Religião e sociedade. Dois ensaios. Imprensa de Ciências Sociais.

Bernardino, F. M. C. (2007). O Segredo de Fátima. Ensaio de hermenêutica teológica. Universidade Católica Portuguesa.

Burke, P. (2005). O que é História Cultural? Jorge Zahar Editor.

Catroga, F. (2006). Entre Deuses e Césares. Secularização, laicidade e religião civil. Uma perspectiva histórica. Almedina.

Christian Jr., W. A. (1996). Visionaries. The Spanish Republic the Reign of Christ. University of California Press.

Coutrot, A. (2003). Religião e Política. In R. Rémond (Ed.), Por uma História Política (pp. 331-363). FGV.

da Silva, E. M. (2010). Viajantes e Missionárias. gênero e religião entre as protestantes norte-americanas no Brasil (1870-1920). Campinas: Universidade Estadual de Campinas.

da Silva, E. M. (2012). “Os Anjos do Progresso no Brasil”: as missionárias protestantes americanas (1870 - 1920). Rever (01), pp. $103-126$.

da Silva, P. J. (2016). Entre a evangelização e a política. a expansão missionária batista para o Brasil Central (1925-1939). Campinas: Universidade Estadual de Campinas.

da Silva, R. M. F. (2016). "Eu sou a graça”. As aparições de Nossa Senhora das Graças em Pernambuco - História e Teologia em confronto em busca da verdade. Ecclesiae.

de Moura, C. A. S. (2018). Histórias Cruzadas. Intelectuais no Brasil e em Portugal durante a Restauração Católica (1910-1942). Imprensa de Ciências Sociais; Universidade de Lisboa.

Diocese of Pesqueira. (1937). Ultimas apparições em genipapinho. Diocese of Pesqueira. 
Fontes, P. F. de O. (2011). Elites Católicas em Portugal. O papel da Acção Católica (1940-1961). Fundação Calouste Gulbenkian; Fundação para a Ciência e Tecnologia.

Gasbarro, N. (2006). Missões: A Civilização Cristã em Ação. In P. Montero (Ed.), Deus na Aldeia. Missionários, índios e mediação cultural (pp. 67-109). GLOBO.

Gasbarro, N. (2013). Religione e/o religioni? la sfida dell'antropologia e della comparazione storicoreligiosa. In E. M. de A. Maranhão Filho (Ed.), Em(Re)conhecendo o sagrado. Reflexões teórico-metodológicas dos estudos de religiões e religiosidades (pp. 83-106). Fonte Editorial.

Gasbarro, N. (2014). A modernidade ocidental e a generalização de "religião" e "civilização": o agir comunicativo das missões. In N. de B. Almeida \& E. M. da Silva (Ed.), Missão e Pregação. A comunicação religiosa entre a História da Igreja e a História das Religiões (pp. 189-210). FAP; UNIFESP.

La Puma, Card. V. (1917). Codice di Diritto Canonico. Società Editrice Internazionale.

Lampeão em território pernambucano? (1936, May 22). Jornal Pequeno, 3.

"Lampeão" está em território pernambucano. (1936, October 22). Diário de Pernambuco, 1.

Lopes, F. R. L. (2012). Práticas Sociais e Discursos Políticos em Torno de Cultos Populares. Universidade Técnica de Lisboa.

Marques, T. P. (2012). De corpo e alma na margem: catolicismo, santidade e medicina no Norte de Portugal. Topoi, 13(25), 147-167.

Miceli, S. (2009). A elite eclesiástica brasileira: 1890-1930. Companhia das Letras.

Miscelanea. (1912, March 24). Gazeta de Pesqueira, 4.

No logar onde apparece a Santa está jorrando agua milagrosa. Segunda-feira estiveram em Cimbres mas de três mil pessôas. (1936, September 15). Jornal Pequeno, 1.

Olinda Misteriosa. (1934, August 18). Jornal Pequeno, 1.

Ratzinger, J. (2000). Comentário Teológico. http://www.vatican.va/roman_curia/congregations/cfaith/documents/rc_con_cfaith_doc_20000626_message-fatima_po.html

Reis, B. C. (2001). Fátima: a recepção nos diários católicos (1917-1930). Análise Social, (XXXVI), 249-299.

Salgado, P. (1955). Manifesto da Ação Integralista Brasileira, 1932. In P. Salgado (Ed.), Obras Completas (pp. 133-154). Américas.

Silva, G. B. (2017). Integralismo e Estado Novo. Diálogos e confrontos. Universidade Federal Rural de Pernambuco.

Simpson, D. (2014). A Igreja Católica e o estado novo salazarista. Edições 70.

Suposta aparição de uma santa. (1936, July 21). Jornal Pequeno, 3.

Tavares, J. S. (1931). Fátima e Lourdes. Brotéria, XII(V), 273-287.

Trindade, H. (1979). Integralismo. O fascismo brasileiro dos anos 30. Difel.

Verde, G. V. (2016). Maria Milza. Milagres e mistérios no sertão da Bahia. Albatroz.

Visão confortadora! Duas creanças, perdidas na matta, viram Nossa Senhora. (1936, September 2). Jornal Pequeno, 1-2. 